\title{
The Discretion of the Judge
}

\author{
The Right Hon. Lord fustice Bingham*
}

A judge of my acquaintance once told me that when, in the course of trying a case, he encountered any problem of unusual difficulty, it was his practice to glower at counsel in his most forbidding manner and demand "Is this not a matter within my discretion?" On counsel agreeing that it was - which it seems they readily did - he would sink back in his chair with relief, relaxed in the knowledge that no matter what he decided his decision would be immune from successful challenge on appeal.

The complaisance of counsel may seem surprising, given the consequence for their clients of a decision being regarded as discretionary. But judges and practitioners have, I think, habitually used the expression "judicial discretion" in a variety of senses, and academic writers have used it in a different sense again. This lack of consensus is also surprising. Since at latest 1581, authoritative voices on both sides of the Atlantic, $\mathrm{Coke}^{2}$, Mansfield ${ }^{3}$ and Marshall ${ }^{4}$ among them, have urged that the discretionary powers of judges and justices be strictly limited and controlled by the law to avoid the arbitrariness of an unpredictable personal decision. Right down to this century, strong language has been used. "To remit the maintenance of constitutional right to the region of judicial discretion", said Lord Shaw of Dunfermline in 1913, "is to shift the foundations of freedom from the rock to the sand." Or as Justice William Douglas put it, "Absolute discretion, like corruption, marks the beginning of the end of liberty." Glaisdale expressed the traditional view when he said, speaking on the judicial discretion to admit or exclude evidence, "And if it comes to the forensic crunch . . . it must be law, not discretion, which is in command."

* The Royal Bank of Scotland Lecture, Oxford University, printed by arrangement with Lord Justice Bingham, and the Royal Bank of Scotland.

1. Lambarde, Eirenarcha, 58.

2. Prohibitions del Roy (1607) Co. Rep. 63, at 64-65.

3. $R$. v. Wilkes (1779) 4 Burr. 2527 , at p.2539.

4. Osborn v. The Bank of the United States (1824) 22 U.S. 738, at p.866.

5. Scott v. Scott [1913] A.C. 417, at p.477.

6. State of New York v. United States (1951) 342 US 822, at p.884.

7.D. v. NSPCC [1978] A.C. 171 , at p.239 G. 
Any lack of certainty as to what judicial discretion is may also be thought undesirable. For if, as these warnings suggest, judicial discretions are dangerous as capable of leading to arbitrariness, it is as well judges should be quite clear when they are exercising a discretion and when not, and if the exercise of a discretion is a barrier (whether or not surmountable) to an appeal then appellate judges should similarly recognise when the barrier exists and when it does not.

I am vividly aware that he who defines invites scholarly refutation, and to attempt the task in this forum may reasonably be thought foolhardy. I shall nonetheless proffer a definition, and briefly defend it. On the assumption that my definition is broadly acceptable, I shall then suggest that the role of judicial discretion is now narrowly confined. I shall further suggest, with appropriate apologies to Mr Dunning, as he then was, that its role has decreased, is decreasing and need not in general be much further diminished. The dragon of arbitrary discretion has not been slain, but it has been domesticated and put on a short leash.

According to my definition, an issue falls within a judge's discretion if, being governed by no rule of law, its resolution depends on the individual judge's assessment (within such boundaries as have been laid down) of what it is fair and just to do in the particular case. He has no discretion in making his findings of fact. He has no discretion in his rulings on the law. But when, having made any necessary finding of fact and any necessary ruling of law, he has to choose between different courses of action, orders, penalties or remedies he then exercises a discretion. It is only when he reaches the stage of asking himself what is the fair and just thing to do or order in the instant case that he embarks on the exercise of a discretion.

I believe this definition to be broadly consistent with the usage adopted in statutes. There are of course numerous statutes which confer a discretion on the court, describing it as such; many of these relate to the award of costs, the imposition of criminal penalties and the exercise of procedural powers, all of them pre-eminently discretionary fields. To some examples I shall return. But often a discretion is conferred although not so described: ". . may, in accordance with the rules of court, extend any such period to such extent and on such conditions as it thinks fit ..."; "may order that such party be at liberty to inspect and take copies of any entries in a banker's book ..."; "may ... as it thinks fit", "may . . . as the court thinks just"; "may impose such other condition as it thinks fit"; " "On an application under this section the court may make or refuse to make the declaration asked for ..."; 11 and so on, almost ad infinitum. A discretion is conferred whichever form of words is used.

While my exploration of the statute book is far from comprehensive, I have encountered only two provisions which are inconsistent with my suggested

8. Maritime Conventions Act 1911, s.8.

9. Bankers' Books Evidence Act 1879, s.7.

10. Housing Act 1988, s.9(1)(2)(3).

11. Local Government Finance Act 1982, s.19. 
definition. The first is in section 2 of Fox's Libel Act 1792 which provides "That, on every such trial, the Court or Judge before whom such indictment or information shall be tried, shall, according to their or his Discretion, give their or his Opinion and Directions to the Jury on the Matter in Issue between the King and the Defendant or Defendants, in like manner as in other Criminal Cases." I would have to admit that the direction which a judge gives to a criminal jury on the law is not now a matter of discretion within my definition. But the next section uses the term in my sense: it provides that nothing shall "prevent the Jury from finding a Special Verdict, in their Discretion, as in other Criminal Cases." The second exception occurs in section 25 of the Children and Young Persons Act 1933, the product of an age happily innocent of teenage pop-stars and tennis prodigies. It forbids anyone having the custody of a person under 18 to cause or permit such person to go abroad for the purpose of singing, playing, performing or being exhibited for profit without a licence from a police magistrate. The magistrate may vary or revoke such a licence "for any cause which he, in his discretion, considers sufficient."'12 Now I would have no quarrel if the magistrate were given power in his discretion to vary or revoke for sufficient cause, and that may be what the sub-section means, but I could not accept that a cause could be sufficient simply because the magistrate considered it so. The sub-section may, however, only be intended to provide that the police magistrate's judgment on sufficiency should be final, not an unusual provision when decisions are entrusted to administrators. These exceptions may scratch the paintwork of my definition; they do not, I think, hole it below the water-line.

It might be thought unnecessary to stress that the judge has no discretion in making findings of fact. But judges do sometimes describe fact-finding as discretionary. That learned and accurate judge, the late Sir Brian MacKenna (who resembled Gibbon in nothing save his account of what he owed the University of Oxford), referred to "the judge's other great discretionary power, that of finding the facts when he tries a case alone."13 Lord Brightman referred to the existence or non-existence of a fact as being left to the judgment and discretion of a public body. ${ }^{14}$ Justice Barak of the Israel Supreme Court has written "The first area of judicial discretion deals with deciding the facts." 15 Now it is one thing to say that the responsibility of finding the facts is entrusted to a particular person or body, be he judge, arbitrator, official or public authority, and that such finding is to be treated as conclusive or virtually so. But it is quite another to describe that function as discretionary. It is, I suggest, nothing of the kind. In finding the facts the judge's job is to consider all the conflicting evidence this way and that and decide as best he can where the truth lies. It is very much the task performed, for instance, by the historian or the journalist as part of his stock in trade. The judge is

12. S. $25(5)(a)$.

13. "Discretion", The Irish furist, Vol. IX (new series) 1, at p.9.

14. $R$. v. Hillingdon London Borough Council, ex p. Pulhofer [1986] A.C. 484, at p.518.

15. Judicial Discretion (1989), at p.13. 
of course constricted by formalities and rules of evidence which do not afflict them. On the other hand, he has powers of compelling testimony which they would envy. It is nonetheless essentially the same function. Yet to say of a historian or a journalist that he exercised a discretion in reaching conclusions of fact would, I suggest, be regarded as libellous. The judge must exercise judgment, not discretion, in finding the facts, and it is usually the most difficult and often the most exacting task which the civil trial judge has to undertake. It calls for a degree of rigour which is disguised by references to choosing between competing accounts of a disputed event or preferring the evidence of one witness to that of another, and to speak of discretion in this context is to open the door to potentially dangerous habits of thought. It can lead to such absurdities as assessing expert evidence on the demeanour of the expert or such errors as finding a fact to be established because it has been denied by a witness held to be unreliable. It can encourage excessive reliance on the judge's hunch and intuition, neither of them an invariably safe basis for decision. ${ }^{16}$ The judge must decide, in as objective a manner as the materials permit, which version of a disputed event (if either) he accepts as the more convincing; once he has done so he has no choice, whether that conclusion makes the overall resolution of the case more difficult or less so. When reference is made to the trial judge's discretion to decide the facts, what is really meant is that appellate courts will usually be reluctant to interfere with his findings because he, having seen and heard the witnesses, is in a better position to decide whose evidence is reliable than anyone else. In cases turning largely on oral evidence, this is doubtless very often true: the trial judge's immediate contact with the witnesses and the unfolding drama of litigation gives him insights denied to those who come later. It is the advantage which the journalist on the scene at the time enjoys over the historian. And even if the judge may be wrong, no one else can be sure of being right. But it is well, even in this class of case, to preserve a measure of scepticism. As Lord Wilberforce has recently observed:

"English judges entertain the belief that they can tell if a man - or even a woman - is speaking the truth. This is a Palladium: and it has comforting consequences: 'The judge saw the witness in the box - observed his demeanour'. 'He was disbelieved by the judge - or the jury'. 'We (the appeal court) cannot interfere'. But there is not much scientific basis for this. Such studies, as I know of, show that liars are believed as often as truth-tellers are disbelieved. And one can test it with multiple tribunals - e.g. arbitrations, whether all British or from different nations. I can give several instances where exactly opposite views as to credibility were confidently given by members of such tribunals - a fact which encourages people to avoid oral evidence before them. Indeed, one often finds foreign arbitrators irritated with the English style of examination and cross-examination - it is not a good way of getting at the truth or persuading the tribunal."17 
Further, the very immediacy of the trial judge's impressions can sometimes cloud his judgment. There are, I think, more cases than is generally acknowledged, particularly those largely dependent on documentary or expert evidence, in which the insights of the trial judge are less reliable than the more detached reflection of an appellate court as those of the journalist sometimes are than those of the historian. I fear I have digressed, but I would wish firmly to exclude the notion of discretion from the very important area of factual decision.

In boldly asserting that a judge does not exercise discretion in giving his rulings on the law I have, I appreciate, side-stepped a very high level philosophical debate conducted by Professors Hart, Dworkin, MacCormick, Raz and others. ${ }^{18}$ I fear that my offering on the sergeant directed to take his five most experienced men on patrol would be of small value anyway, but it is plain that decisions on the law fall well outside my definition of judicial discretion. This is not in any way to criticise the usage of others; the English language is a rich pasture open to all. But on this point at least I think I can rely on the invariable usage of the practising profession in this country. It is a distinction regularly drawn when leave is sought to appeal against an interlocutory decision, the judge's usual practice being to grant leave if he has decided a question of law and to refuse it if he conceives himself to have exercised a discretion. There may well be uncertainty where discretion begins and ends but there is unanimity that it falls short of legal rulings. I would, however, offer one observation prompted by the philosophical debate. There are occasions when judges think that they are required to elect between different legal solutions and, in effect, create new law. Usually, even in cases that turn on the law, the question is whether the given case falls within an established principle or which of two established principles governs it. But there are occasions when existing lines of authority fall short of the given case and the question is whether they should be extended to cover it. Donoghue v. Stevenson ${ }^{19}$ is perhaps the most obvious example; hence, no doubt, the divergence of opinion in that case. There are other, rarer, occasions when a problem seems to occur in an authoritative desert, where the usual aids - principle, precedent, dicta and the opinions of learned authors - are virtually absent. The judge cannot then simply extend the line on an existing graph of authority because there is none. It is surely true that when judges buttress their conclusions with references to public policy, commercial good sense, certainty, good industrial relations and so on it is because they are conscious of making a choice and are, quite properly, concerned to justify the choice that they have made.

The role of discretion in the balancing exercises which the courts are, it seems increasingly, invited to carry out is not altogether easy to determine. For instance, in balancing the public interest in withholding official documents against the public interest in the administration of justice, ${ }^{20}$ or in weighing the competing

18. See,e.g. , H.L.A. Hart, The Concept of Law (1961); R. Dworkin, Taking Rights Seriously (1977); N. MacCormick, Legal Reasoning and Legal Theory (1978); J. Raz, The Authority of Law (1979); A. Barak, Fudicial Discretion (1989).

19. [1932] A.C. 562.

20. Conway v. Rimmer [1968] A.C. 910 , at p.952 A. 
public interests in disclosure and non-disclosure, ${ }^{21}$ or for and against publication ${ }^{22}$ or in the maintenance of confidence against disclosure, ${ }^{23}$ or between maintaining professional confidences and protecting the public against possible violence, ${ }^{24}$ is the judge exercising a discretion and if so to what extent? Some would, I think, regard this exercise as largely if not wholly discretionary. ${ }^{25}$ But I do not think the factors to be put into the scales are the subject matter of discretion. They are matters established, or held to be established, by evidence, or more rarely matters of which judicial notice may be taken. Discretion has nothing to do with that, as I have already suggested. In the English Spycatcher ${ }^{26}$ litigation, for instance, detailed evidence was adduced to show why publication would damage national security; the trial judge discounted most of this, but in doing so he was not, at least in my terms, exercising a discretion. In assessing the weight to be given to various factors for and against any decision, much must of course turn on the judgment of the individual assessor, and for this reason an appeal court will be slow to interfere with a value judgment on which reasonable minds could differ. Strictly, however, I think it is probably only at the last stage of striking a balance and granting or refusing relief that one moves into the realm of pure discretion. For this view, I hope I may enlist the aid of Lord Diplock. In Birkett v. Fames, ${ }^{27}$ speaking of interlocutory decisions, he said:

"They are decisions which involve balancing against one another a variety of relevant considerations upon which opinions of individual judges may reasonably differ as to their relative weight in a particular case. That is why they are said to involve the exercise by the judge of his 'discretion' . . . when leave is granted, an appellate court ought not to substitute its own 'discretion' for that of the judge merely because its members would themselves have regarded the balance as tipped against the way in which he had decided the matter. ..."

That may sound like somewhat doubtful aid. But on both occasions when Lord Diplock, a stickler for accurate usage, spoke of discretion in that passage he put the expression in inverted commas, to indicate, as I infer, that he was not referring to an exercise of discretion properly so called.

The role of judicial discretion today is, I suggest, subject to one exception, fairly narrowly confined. For that proposition I summon up the weighty support of Sir Wilfred Greene MR:

21.D. v. NSPCC [1978] A.C. 171, at p.219C.

22. British Steel Corporation Ltd. v. Granada Television Ltd. [1981] A.C. 1096, at p.1202 C.

23. A.G. v. Guardian Newspapers (No. 2) [1990] A.C. 109, at p.282.

24. W. v. Egdell [1990] 2 W.L.R. 471, at p.491 A.

25. E.g., Barak, fudicial Discretion (1989), at p.68.

26. A.G. v. Guardian Newspapers (No 2) [1990] A.C. 109.

27. [1978] A.C. 297, p.317 D. 
"In all discretionary remedies it is well known and settled that in certain circumstances - I will not say in all of them, but in a great many of them - the Court, although nominally it has a discretion, if it is to act according to the ordinary principles upon which judicial discretion is exercised, must exercise that discretion in a particular way, and if a judge at a trial refuses to do so, then the Court of Appeal will set the matter right." 28

That was said 50 years ago, but it is even truer today, as can (I think) be demonstrated by reference to the areas in which discretion is most obviously exercised.

I start with the award of costs. A series of statutes entrusts this to the discretion of the court or arbitrator. ${ }^{29}$ Notably, section 51 of the Supreme Court Act 1981 provides that costs shall be in the discretion of the court which "shall have full power to determine by whom and to what extent the costs are to be paid." So special is this discretion that rights of appeal are specifically restricted, ${ }^{30}$ and its width has been recently emphasised by the House of Lords. ${ }^{31}$ It is nevertheless universally recognised as the primary principle governing courts and arbitrators in the exercise of their discretion that costs should follow the event ${ }^{32}$ and to depart from that rule without showing sufficient reason is to raise a rebuttable presumption of error. ${ }^{33}$ It is of course necessary to identify the event, which in a tangle of claims and cross-claims may not be straightforward, but a party's entitlement to receive costs or responsibility to pay them is first to be judged by reference to his success or failure in the litigation. ${ }^{34}$ This primary principle may not be applied in its full rigour, for example where a party's conduct in the litigation $^{35}$ justifies a departure or where the successful party recovers less than had earlier been offered or paid into court, ${ }^{36}$ but a well-established body of authority ${ }^{37}$ shows that a judge is by no means free to indulge his personal whims or prejudices when awarding costs. The reality is revealed by the traditional exchange between the court and counsel for the unsuccessful party when the victor asks for costs. "You can't resist that, can you, $\mathrm{Mr}$ X?" to which the answer, much more often than not, is "No" although, at least in the Court of Appeal, he usually adds "But I have an application to make." A discretion exists, but within a compass which is well understood and has, I think, shrunk over the years.

The field Sir Wilfred Greene had in mind in the passage quoted was that of

28. R. v. Stafford fustices [1940] 2 K.B. 33, at p.43.

29. E.g., Arbitration Act 1950, s.18; Magistrates Courts Act 1980, s.64; Highways Act 1980, s.209;

County Courts Act 1984, s.45; Agricultural Holdings Act 1986, Sched. 11, para 23.

30. Supreme Court Act 1981, s.18(1)(f).

31. Aiden Shipping Co. Ltd. v. Interbulk Ltd. [1986] A.C. 965, at pp.975, 979 D.

32. The Erich Scroeder [1984] 1 Lloyd's Rep. 192, at p.194.

33. Tramountana Amadora SA v. Atlantic Shipping Co. $S A$ [1978] 1 Lloyd's Rep. 391, at p.394.

34. Archital Luxfer Ltd. v. Henry Boot Const ruction Ltd. [1981] I Lloyd's Rep. 642, at p.650.

35. Ibid., at p.650; Video Box Office Ltd. v. GST Holdings Ltd., [1990] The Independent, 27 April.

36. The los $I$ [1987] 1 Lloyd's Rep. 321.

37. See Supreme Court Practice (1988) Vol 1, 62/2/10 et seq. 
remedies, and it is elementary that equitable remedies are discretionary and not a matter of right. But over a century has now passed since Lord Blackburn said: ${ }^{38}$

"The jurisdiction of the Court of Equity to enforce the specific performance, or to grant an injunction to prevent the breach of a covenant, is no doubt a discretionary jurisdiction, but I perfectly agree with the view expressed by your Lordships that the discretion is not one to be exercised according to the fancy of whoever is to exercise the jurisdiction of Equity, but is a discretion to be exercised according to the rules which have been established by a long series of decisions, and which are now settled to be the proper guide to Judges in Courts of Equity."

\section{Even earlier Lord Kingsdown had said: ${ }^{39}$}

"The rule I take to be clearly this: if a Plaintiff applies for an injunction to restrain a violation of a common law right, if either the existence of the right or the fact of its violation be disputed, he must establish the right at law; but when he has established his right at law, I apprehend that unless there be something special in the case, he is entitled as of course to an injunction to prevent the recurrence of that violation."

The circumstances which may deprive a plaintiff of his remedy are well established: there is no likelihood of repetition; damages will be an adequate remedy; the plaintiff has acquiesced in the defendant's conduct; the plaintiff's conduct has disentitled him from seeking relief; and so on. Whether these impediments exist may involve an exercise of judgment, or findings of fact which an appeal court may be slow to disturb, but will not involve an exercise of discretion. If they do not exist, whether the remedy be injunction or any other equitable remedy, there is virtually no ground for refusing relief. If they do, an exercise of discretion will be called for but usually within a strictly confined area and it will be readily reviewable. The recently developed field of Mareva injunctions illustrates the point very clearly: the conditions for granting such an injunction have been clearly laid down; ${ }^{40}$ where the affidavit evidence shows the conditions to be met, the judge is almost bound to grant relief. Many a judge, instinctively reluctant to grant this draconian relief, has in practice found it almost impossible on a reasonably well-prepared application to find grounds for refusing to do so.

At this point the well-informed schoolboy would doubtless interject that remedies in public law at least must be truly discretionary, because the judges are

38. Doherty v. Allman (1878) 3 App. Cas. 709, at p.728.

39. Imperial Gas Light $\mathcal{E}$ Coke Co. v. Broadbent (1859) 7 H.L.C. 600, at p.612. See also Fullwood v. Fullwood (1878) Ch. D. 176, at p.179.

40. See Gee, Mareva Injunctions \& Anton Piller Relief, 2nd ed. (1990), at pp.10-11. 
always saying so. He would be right. They are. And the judges are right too. It is therefore possible, as Professor Wade says, ${ }^{41}$ "that the court may find some act to be unlawful but nevertheless decline to intervene." But there is a wide gap between the rhetoric and the reality. The constraints of time and the limitations of my own research do not enable me to discuss the subject in detail or pronounce with authority. I have, however, a very strong hunch that in the decade since the Crown Office List became a boom town there would turn out to be no more than a handful of cases in which excess or abuse of power had been established but a remedy refused. In these few cases, the reason for the refusal of relief would (I suspect) usually turn out to be that the applicant had disentitled himself to relief by his own conduct, that the illegality was of a technical nature, ${ }^{42}$ that delay in application had made relief futile or impracticable, or that the public authority was willing to give effect to the decision without the formality of an order against it. The much trumpeted principle that an applicant for judicial review must first exhaust his other remedies ${ }^{43}$ does not seem often in practice to have led to a denial of relief.

In the procedural field at least one might expect the judge, as master of proceedings in his court, to exercise an almost unfettered discretion. Many statutes and rules of court confer apparently wide discretions, but each is quickly confined between banks of practice and authority. The court may extend the validity of a writ, says the rule; ${ }^{44}$ but only for good reason say the cases, ${ }^{45}$ which also give guidance on what may and may not be a good reason. ${ }^{46}$ If certain conditions are satisfied, the court may order the plaintiff to give such security for the defendant's costs as it thinks just if having regard to all the circumstances of the case it thinks it just to do so; ${ }^{47}$ but the principles on which the discretion is exercised are in general so well understood that contests save as to amount are relatively unusual. ${ }^{48}$ The court may stay an action on grounds of forum non conveniens, but authoritative guidance on the exercise of the discretion is now found in The Spiliada. ${ }^{49}$ If certain conditions are satisfied, the court may if it thinks fit make an order for interim payment of such amount as it thinks just; ;0 but experience shows the mortality rate among such orders to be high. ${ }^{51}$ The court may, if of opinion that in the circumstances of the case undue hardship would otherwise be caused, and on such terms if any as the justice of the case may require,

41. Wade, Administrative Law 6th ed. (1988), p.709.

42. E.g., R. v. Governors of Bacon's School, ex p. ILEA [1990] The Independent, 29th March.

43. Wade, supra n. 41 , at p.714.

44. RSC 0. 6 r. $8(2)$.

45. In particular, Kleinwort Benson Ltd. v. Barbrak Ltd. [1987] A.C. 597.

46. See generally, Supreme Court Practice 1988, 6th Cum. Supp., p.9, para. 6/8/3.

47. RSC O. 23 r. $1(1)$.

48. The advent of the European Community has, however, raised new questions: Porzelack $K G \mathrm{v}$. Porzelack (UK) Lid. [1987] I W.L.R. 420; De Bry v. Fitzgerald [1990] I All E.R. 560.

49. $[1987]$ A.C. 460.

50. RSC O. 29 r. $11,12$.

51. See, e.g., British \& Commonwealth Holdings p.l.c. v. Quadrex Holdings Inc. [1989] Q.B. 842. 
extend the time for commencing arbitration proceedings; ${ }^{52}$ but the judge called upon to exercise this jurisdiction is well advised to have regard to the guidance given by $\mathrm{Mr}$ Justice Brandon in The focelyne ${ }^{53}$ which earned the approval of Lord Justice Brandon in The Aspen Trader. ${ }^{54}$ Perhaps no clearer example of how practice develops can be found than in section 69 of the Supreme Court Act 1981 which requires certain specified causes of action to be tried by a jury and provides that any other action shall be tried without a jury "unless the court in its discretion orders it to be tried with a jury." Here, one might think, was a generously framed discretion, capable of being exercised in favour of jury trial for a difficult personal injury case. So, it would seem, the master and the judge thought in Ward v. fames, ${ }^{55}$ decided under the section's predecessor. Yet, said Lord Denning MR: ${ }^{56}$

"it is of the first importance that some guidance should be given - else you would find one judge ordering a jury, the next refusing it, and no one would know where he stood. It might make all the difference to the ultimate result of the case. This would give rise to much dissatisfaction. It is an essential attribute of justice in a community that similar decisions should be given in similar cases, and this applies as much to mode of trial as anything else. The only way of achieving this is for the courts to set out the considerations which should guide the judges in the normal exercise of their discretion. And that is what has been done in scores of cases where a discretion has been entrusted to the judges."

So guidance was given, and jury trials save in the specified cases have vanished from the civil scene, it would seem likely for ever. ${ }^{57}$

Recent experience prompts me to mention an example, drawn from quite a different field, of an apparently wide discretion legislated almost out of existence by judicial decision and finally overtaken by statute itself. Section 30 of the Law of Property Act 1925 permits the trustee in bankruptcy of a bankrupt husband to apply to the court for an order that property owned jointly by husband and wife be sold, and the court may make such order as it thinks fit. This again would have seemed to give the court a very wide discretion to do what seemed right to reflect the respective interests of the creditors on the one hand and the wife and children on the other. But a long line of cases held that the trustee was ordinarily entitled to an order for sale in the absence of "very special circumstances" or "good reasons"

52. Arbitration Act 1950, s. 27.

53. [1977] 2 Lloyd's Rep. 121.

54. [1981] 1 Lloyd's Rep. 273.

55. [1966] I Q.B. 273.

56. Ibid, at p.293.

57. My own personal impression is confirmed by the experience of Master Warren QC, the Senior Master of the Queen's Bench Division, who knows of no such case since Ward v. James except Hodges v. Harland $\mathcal{E}$ Wolff Ltd. [1965] 1 All E.R. 1086, decided some 3 weeks later. And see, most recently Singh v. London Underground Ltd. [1990] The Independent, 25th April. 
or "a substantial case of hardship" or, finally, "exceptional circumstances". ${ }^{88}$ And now the opportunity to question whether a test of exceptional circumstances does not unreasonably constrict the language of the Act has passed, for it has been woven into the 1986 Insolvency Act. ${ }^{59}$

I suppose most of us would today regard the criminal trial as the real sanctuary of judicial discretion. This has a large measure of truth, although even an experienced criminal judge, on reading Rosemary Pattenden's book The fudge, Discretion and the Criminal Trial, would (I think) be surprised at the wealth of his (or her) endowment. ${ }^{60}$ The reason is not far to seek: during the trial the court's management decisions are to a large extent immune from challenge; and once the trial is over, all but the most obviously wrong exercises of discretion tend to be superseded by the verdict of the jury. Pattenden, however, observes ${ }^{61}$ that over the course of this century the attitude of the courts has changed and the court's reluctance to interfere with an exercise of discretion has waned.

A glance at the more recent case law - quite apart from the recent decision concerning the Irish conspirators to murder $\mathrm{Mr}$ Tom King - bears her out. ${ }^{62}$ Thus over the last few months alone the court has interfered with discretionary decisions to allow committal proceedings to continue, ${ }^{63}$ not to stop a case going to the jury ${ }^{64}$ not to discharge a jury, ${ }^{65}$ to accede to a jury's request to be supplied with scales, ${ }^{66}$ to interrupt excessively, ${ }^{67}$ not to direct the jury that previous convictions for dishonesty were relevant only to credibility ${ }^{68}$ and, on many occasions, to admit admissible but prejudicial evidence. One recalls that twenty years ago the Court of Appeal (Criminal Division) declined to interfere when a chairman of quarter sessions had on repeated occasions during a defendant's case observed in a loud voice "Oh, God", and then laid his head across his arm and made groaning and sighing noises. Counsel had not, the Court held, been positively and actively obstructed in the doing of his work and the chairman's conduct, if it might be regarded as discourteous and as showing signs of impatience, disparaged only the defendant's counsel, not his case. ${ }^{69}$ I do not think this decision was found convincing even at the time, at any rate by advocates with personal experience of the chairman in question, but I am quite confident that the judge's discretion to conduct a criminal trial as he wishes would today be much more rigorously scrutinised.

58. Re Holliday [1981] Ch 405, at pp.419 G, 420 B, E 415 F, 424 C, 425 H; Re Lowrie [1981] 3 All E.R. 353 , at p.355 j.

59. S. $356(5)$.

60. Op. cit., Appendix, at p.183.

61. Op. cit., at pp.21, 22.

62. $R$. v. Cullen and Others [1990] The Independent, 1 May.

63. R. v. Sunderland Magistrates Court, ex p. Z. [1989] Crim.L.R. 56.

64. R. v. Morley [1989] Crim.L.R. 566.

65.R. v. Jaquith, Emode [1989] Crim.L.R. 563.

66. R. v. Stewart Sappleton [1989] Crim.L.R. 653.

67. R. v. Renshaw [1989] Crim.L.R. 811.

68.R. v. Prince [1990] Crim.L.R. 49.

69. R. v. Hircock, Farmer, Leggett [1970] 1 Q.B. 67. 
The accelerating tendency towards a narrowing of discretion is nowhere better illustrated than in the field of sentencing. As long ago as 1361 justices of the peace were empowered to punish offenders "according to that which to them shall seem best to do by their discretions and good advisement", ${ }^{70}$ and in later centuries the sentencing discretion was often described in statutes as such. ${ }^{71}$ Interestingly, in view of the new (and to my mind obnoxious) American practice of prescribing maximum and minimum penalties within a very narrow band, one may note that the Slave Trade Act 1824 imposed as the penalty for dealing in slaves, transportation for a term not exceeding 14 years or hard labour for a term not exceeding 5 years nor less than 3 years at the discretion of the court. The practice of prescribing minimum sentences did not, happily, catch on. It does, however, seem almost incredible, looking back, that there should for so many centuries have been no effective judicial means of challenging the exercise of the sentencing discretion on the ground that a penalty, though lawful, was excessive. The first statutory step towards controlling the discretion of course came with the establishment of the Court of Criminal Appeal in 1907, which could substitute such sentence as it thought should have been passed at the trial (whether more or less severe). ${ }^{72} \mathrm{But}$ the Court got off to a slow start: such was the respect felt for the sentencer's discretion that in 1908, when the Act was in operation for nine months, only 14 sentences were reduced ${ }^{73}$ - roughly the tally today on an average week-day morning. It might be objected that giving a right of appeal against sentence was merely to substitute the discretion of three judges for that of one, but any appellate court is in particular constrained to build up a body of precedent and seek to achieve a reasonable level of consistency, so that the clear result was progressively to narrow the sentencer's discretion. But I think it is really only in relatively recent times that the judge's discretion in passing sentence has been subjected to the degree of discipline familiar in other fields. To this a number of causes have contributed. One, without doubt, has been the entry into the field of distinguished academic analysts, particularly Dr David Thomas, but also others. Linked with that is the systematic reporting of decisions on sentence. Another cause is the work of the Criminal Division itself. When, twenty years ago, Widgery LJ spoke of the well-known duty of the Criminal Division "to lay down principles and guidelines to assist sentencers of all grades in the application of the discretion which the imposition of sentence requires", ${ }^{74}$ he was speaking no less than the truth. But it is over the last decade that, for the first time, a serious attempt has been made to provide detailed guidance on sentencing in a systematic, rational and explicit way.

70. Justices of the Peace Act 1361.

71. E.g. , Offences against the Person Act 1861; Foreign Enlistment Act 1870.

72. The Criminal Appeal Act 1907, s.4(3).

73. Holdsworth, History of English Law, vol. I, at p.218.

74. R. v. Newsome and Browne (1970) 54 Cr. App. Rep. 485, at p.490. 
One thinks of the landmark decisions in such fields as rape ${ }^{75}$ the importation of drugs ${ }^{76}$ theft in breach of trust, ${ }^{77}$ serious disorder, ${ }^{78}$ killing by dangerous driving, ${ }^{79}$ and others. For years it was customary to challenge sentences as being wrong in principle but it was often far from easy to identify any principle. The introduction of principle into this field will, I think, be seen as the enduring and in many ways personal achievement of the present Lord Chief Justice. This is a development to be whole-heartedly welcomed. Without explicit guidelines there can be no informed public debate on sentencing practice, and the appropriate punishment of offenders against society is a proper matter for consideration by society (if for purposes of argument one assumes there to be such a thing). Such consideration is no more an encroachment on the judges' independence than the prescription of maximum penalties by statute, which has always of course been accepted. It is absurd to suppose that the judges could properly have a sentencing policy of their own independently of the society of which they form part. Another cause contributing to the narrowing of discretion has been vocal public dissatisfaction with a sentencing regime which has been frequently portrayed, on occasion fairly, as arbitrary, even whimsical, and inadequately controlled. This dissatisfaction has not in the main arisen from sentences seen as unduly severe, which have after all been amenable to review on appeal, and the cases show that the Criminal Division has been willing (often to the fury of sentencers) to make quite minor adjustments of sentence when it felt that justice required them. The real clamour has concerned sentences seen as unduly lenient and the new power to refer such sentences to the Court ${ }^{80}$ must be understood both as a response to that body of opinion and as a guarantee of the judicial guidelines. The upshot of all these developments is certainly not that the sentencer has lost his discretion. He has not. The guideline cases are only guidelines. The facts of two cases and the personal circumstances of two defendants are never the same. The primary responsibility of passing the appropriate sentence remains with the sentencer, whose decision in the vast majority of cases is never the subject of appeal. But I think it is undoubtedly true that this discretion has become much more judicial in the sense that it is exercised in a much more structured framework and is subject to much narrower constraints and is much more readily reviewable than it ever used to be.

In a quite different corner of the criminal field, I think we have a golden opportunity to observe the organic development of a somewhat novel discretion in something approaching laboratory conditions. The criminal judge has long enjoyed a discretion to exclude evidence of which the prejudicial effect is thought likely to outweigh the probative value. But the Police and Criminal Evidence Act 1984 moved the goalposts: it provided for the issuing of codes governing such

75. R. v. Billam (1986) Cr. App. R.(S) 48.

76. R. v. Aramah (1982) 4 Cr. App. R.(S) 407; R. v. Martinez (1984) 6 Cr. App. R.(S) 364.

77. R. v. Barrick (1985) 81 Cr. App. R. 78.

78. R. v. Keys (1986) 8 Cr. App. R. (S) 444.

79. R. v. Boswell (1984) 6 Cr. App. R. (S) 257.

80. Criminal Justice Act 1988 , s. 36(I). 
matters as the questioning of suspects, ${ }^{81}$ provided that the codes should be taken into account in determining any question in proceedings to which they were relevant ${ }^{82}$ gave suspects a right under section 58 (albeit qualified) to take legal advice and (relevant for present purposes) conferred a discretion on the court under section 78(1) to "refuse to allow evidence on which the prosecution proposes to rely to be given if it appears to the court that, having regard to all the circumstances, including the circumstances in which the evidence was obtained, the admission of the evidence would have such an adverse effect on the fairness of the proceedings that the court ought not to admit it." How was this discretion to be exercised? As was observed in a recent case, with some degree of under-statement, "When the Act came into force the effect which the Courts would give to this section was in doubt." 83 One view, although not so crudely put, was that the proceedings did not become unfair if evidence was admitted which led to the conviction of a guilty defendant, whether or not a breach of the non-binding codes had occurred. This was not much different from the approach previously taken to breaches of the Judges' Rules. The other view was that since Parliament had intended a defendant to enjoy certain safeguards the proceedings became unfair if he was denied them and was convicted as a result. Plainly the risk existed that different judges would adopt highly divergent practices, with the unacceptable consequence that a decision of possibly crucial importance to the criminal defendant would turn on the predilections of the individual decision-maker. One could not, I think, claim that any wholly coherent approach to this very wide discretion has yet been formulated, but if one looks at the cases where section 58 or the codes have been breached and reliance is placed on section 78 , in the relatively very short period since the 1st January 1986 when the section came into force, the elements of such an approach may perhaps be discerned. It has been repeatedly stated that a breach of section 58 or the codes does not of itself require evidence of a confession to be excluded ${ }^{84}$ but there has nevertheless been a growing and possibly even exaggerated tendency to exclude. In the cases where evidence has been held to be rightly admitted, despite breaches, the reason has been given that the defendant was well aware of his rights and access to a solicitor would not have improved his position ${ }^{85}$ or more generally that in all the circumstances of the particular case the breaches did not affect the fairness of the proceedings ${ }^{86} \mathrm{But}$ in most of the cases where breaches have been established evidence has been excluded or it has been held that it should have been. The right to legal advice has been described as fundamental. ${ }^{87}$ In a case where there had been wholesale

81. S. 66 .

82. S. 67(11).

83. R. v. Keenan (1989) 90 Cr. App. R. 1, at p.6.

84. R. v. Keenan (1990) 90 Cr. App. R. 1, at p.12; R. v. Walsh [1989] Crim.L.R. 822, at p.823;R. v Matthews [1990] Crim.L.R. 190 .

85. R. v. Alladice (1988) 87 Cr. App. R. 380; R. v. Dunford [1990] The Independent, 30th March.

86. R. v. Waters [1989] Crim.L.R. 62;R. v. Matthezos [1990] Crim.L.R. 190.

87. R. v. Samuel [1988] Q.B. 615, at p.630; R. v. Beycan [1990] Crim.L.R. 185, at p.186. 
breaches it was said that to admit the evidence would be to condone flouting of the provisions designed to protect against confessions which were not genuine. ${ }^{88}$ But it is now clear that in the ordinary way evidence will only be excluded if the breaches are significant and substantial ${ }^{89}$ and the crucial consideration has usually been whether, because of the breaches, the defendant gave answers he might not have given ${ }^{90}$ or has otherwise been prejudiced in resisting the charge. ${ }^{91}$ It may be that the pendulum has swung too far towards exclusion upon breaches being shown, without adequate consideration of the effect on the fairness of the proceedings which the Act requires. ${ }^{92}$ My point, however, is that within about five years of the Act coming into force one sees a discretion drawn in very wide terms being defined and regulated so that the lines upon which judges should exercise it are likely quite soon to become clear and well-understood. While prediction is hazardous, the general shape of the rule seems likely to be that the judge should ordinarily exclude prosecution evidence if there have been significant and substantial breaches of section 58 or the codes and the defendant has as a result given damaging answers which he would not otherwise have given or has been substantially prejudiced in resisting the charge. If this were the broad shape of the rule, difficult borderline cases would no doubt arise, but in the great mass of cases it would be obvious to judges and practitioners how the discretion should and would be exercised. One would also expect that as the consequences of failure to comply with these highly detailed provisions were increasingly borne in upon police forces, the incidence of significant and substantial breaches would sharply decline.

Perhaps the last real stronghold of almost unreviewable discretion is where the care and custody of children are concerned. This is not because demonstrable errors in the judge's balancing exercise in this field will not be corrected: authority shows that they can and should. ${ }^{93}$ It is because, first and most importantly, the evidence is likely to be entirely oral and the issue is likely to turn on the judge's assessment of the personal qualities and motives of the competing parents and other members of the extended family whose capacity as carers is in question. In the absence of some striking mis-judgment it will be almost impossible to show that his conclusion is wrong. And the judge's discretionary decision enjoys a rare inviolability, secondly, because there is in this field usually no satisfactory solution and it is thus impossible for an appellate court to be confident that its view of the less unsatisfactory solution, if different from that of the judge, is superior. ${ }^{94}$ The

88.R. v. Ismail [1990] Crim.L.R. 109, at p.110.

89. $R$. v. Absolam [1989] Cr. App. R. 232, at p. 337;R. v. Keenan (1990) 90 Cr. App. R. 1. at p. 13;R. v. Matthews [1990] Crim.L.R. 10, at p.191.

90. $R$. v. Samuel [1988] Q.B. 615, at p.630; $R$. v. Absolam (1989) 88 Cr. App. R. 332, at p.337; $R$. v. Delaney (1989) 88 Cr. App. R. 338;R. v.Quayson [1989] Crim.L.R. 218;R. v. Walsh [1989] Crim.L.R. 822; R. v. Beycan [1990] Crim.L.R. 190.

91.R. v. Parris (1989) 89 Cr. App. R. 68; R. v. Keenan (1990) 90 Cr. App. R. I; R. v. Fennelley [1989] Crim.L.R. 142;R. v. Britton [1989] Crim.L.R. 144;R. v. Ladlow [1989] Crim.L.R. 219.

92.R. v. Williams [1989] Crim.L.R. 66; R. v. Fogah [1989] Crim.L.R. 141.

93. Re F (a minor) (Wardship: appeal) [1976] Fam. 238; G. v. G. [1985] 2 All E.R. 225.

94. Clarke-Hunt v. Newcombe (1982) 4 F.L.R. 482, at p.488; G. v. G. , supra n. 93, at p.228 b. 
result is, that since the House of Lords endorsed this general approach in $G$ v. $G, 95$ challenges by the aggrieved parent to the trial judge's exercise of discretion have almost always failed. It is not perhaps very happy that an unfettered right of appeal should be effectively abrogated by judicial decision, nor that, in a field where judicial decisions have a unique capacity to cause lasting misery, the trial judge's decision should be effectively final. On the other hand, it would be very hard indeed to suggest any guideline to govern the exercise of this discretion which was not either so obvious or so heavily qualified as to be futile. It would seem that in this limited field, for better or worse, reliance must be placed on the trial judge to show the wisdom, sensitivity and insight of Solomon, although lacking the latter's extra-judicial powers.

May I, in conclusion, touch - much too briefly - on the important issues raised by Professor Atiyah and Professor Treitel in their inaugural lectures respectively twelve and ten years ago?96 Atiyah, it will be recalled, drew attention to the movement over the last century from clear, sharp-edged principles beloved of our Victorian forbears to judgmental discretionary rules thought to be better fitted for dispensing individualised ad hoc justice case by case. Treitel considered this development further with particular reference to the law of contract, showing how certain old rules had been diversified and qualified to cater for hard cases, but suggesting that in the contractual field discretions had not, on the whole, up to then operated so as to create an unacceptable degree of uncertainty. Now certain of the instances discussed by the professors are certainly discretions within my suggested meaning: for example, the rules relating to matrimonial property ${ }^{97}$ or the provision in section 49(2) of the Law of Property Act 1925 enabling the court to order the return of a deposit paid under a contract for the sale of land. ${ }^{98}$ But other instances, although posing judgmental tests, do not involve the exercise of any discretion in my sense: for example, the pervading test of reasonableness in the law of tort,${ }^{99}$ the closest connection test in determining the proper law of a contract, ${ }^{1}$ the test of merchantability now contained in section 14(6) of the Sale of Goods Act $1979,{ }^{2}$ any test based on the intention of the parties, ${ }^{3}$ the new test of common law duress, ${ }^{4}$ or departure from the rule that damages for breach of contract are invariably to be assessed by reference to the time of breach. ${ }^{5}$ None of these permits the judge to apply a simple rule of thumb test. Most require evidence followed by an exercise of judgment, the correctness of which may give rise to differences of

95. Supra, n. 93.

96. P.S. Atiyah, From Principles to Pragmatism, 17th Feb. 1978; G. H. Treitel, Doctrine and Discretion in the Law of Contract, 7th March 1980.

97. Atiyah, op. cit., at p.11.

98. Treitel, op. cit., at p.15.

99. Atiyah, op. cit., at p.11.

1. Atiyah, op. cit., at p.13.

2. Atiyah,op. cit., at p.14.

3. Treitel, op. cit., at p.4.

4. Treitel, op. cit., at p.5.

5. Treitel, op. cit., at p.9. 
opinion. I share to the full the professors' distrust of undirected and unreviewable discretions, but most of the powers they discuss are not, I think, undirected nor, even more importantly, are they unreviewable. We may perhaps take comfort in the fact that even the New Zealand Illegal Contracts Act 1970, which may fairly be regarded as the ultimate in conferment of wide, undefined discretions, is now said, ${ }^{6}$ despite gloomy earlier prognostications, ${ }^{7}$ to have produced a coherent body of decisions. So I, with Treitel, would view the present situation, if not with complacency, at least with a reasonable degree of optimism and confidence. ${ }^{8}$

It is, I think, a deeply rooted instinct of any responsible body, whether a company, a college, a club, a body of trustees, a trade union or anything else, however wide its powers, to endeavour to act with a reasonable measure of consistency. So the tendency to subject a wide discretion to more or less restrictive rules is not a specifically legal phenomenon. Nor, certainly, is it an English phenomenon: a discretion conferred by the New Zealand Matrimonial Property Act 1963 was so mechanically applied by the judges as, in the views of some, to subvert the object of the legislation altogether. ${ }^{9}$

But it is, as shown by that example and others I have discussed, a very marked feature of judicial practice. I do not, therefore, think that whether discretion is understood in my sense or as embracing also the judgmental open-textured rules discussed by the professors there is in general any ground for concern that arbitrary uncontrolled discretion is likely to run riot at the expense of clear discernible principle. Nor do I think that any approach less responsive to the circumstances of particular cases would in general be acceptable to the public as consumers of the judicial product in an age when the public is more inclined to see the law as an ass than as the embodiment of everything that's excellent. But this is, I am conscious, a predictable view from one on the bureaucratic side of the counter. After all, the Lord Chancellor of former days no doubt considered the length of his foot a very convenient, reliable and serviceable measure, happily free of what would now be called resource implications.

6. A Beck, "Illegality and the Court's Discretion: The New Zealand Illegal Contracts Act in Action", (1989) 13 N.Z.U.L.R. 389.

7. M.P. Furmston, "The Illegal Contracts Act 1970 - An English View", 1972, 5 N.Z.U.L.R. 151.

8. Op. cit., at p.20.

9. See Markesinis, "Comparative Law - A Subject in Search of an Audience", (1990) 53 M.L.R. 1, at pp.12-13. 